\title{
The ontogeny of haematopoiesis in the marine teleost Leiostomus xanthurus and a comparison of the site of initial haematopoiesis with Opsanus tau
}

\author{
J. J. Govoni*†, M. A. West*†, J. Bonaventura§q, \\ G. Goddette** And T. E. Jenkins*†† \\ * National Oceanic and Atmospheric Administration (NOAA), National Ocean \\ Service, Center for Coastal Fisheries and Habitat Research, 101 Pivers Island Road, \\ Beaufort, NC 28516-9722, U.S.A., §Duke University, Department of Cell Biology \\ Medical Center and Nicholas School of the Environment, Duke University Marine \\ Laboratory, Department of the Environment, 135 Duke Marine Lab Road, Beaufort, \\ NC 28516-9722, U.S.A. and **Duke University, Nicholas School \\ of the Environment, Duke University Marine Laboratory, \\ Department of the Environment, 135 Duke Marine Lab Road, \\ Beaufort, NC 28516-9722, U.S.A.
}

(Received 6 August 2004, Accepted 11 March 2005)

\begin{abstract}
The ontogeny of haematopoiesis in the perciform fish, spot Leiostomus xanthurus, differed from that reported as the norm for fishes, as exemplified by the cypriniform zebrafish Danio rerio, and observed in the batrachoidiform oyster toadfish Opsanus tau. Erythropoiesis in spot was first evident in the head kidney of yolk-sac larvae 3 days after hatching (DAH). No embryonic intermediate cell mass (ICM) of primitive stem cells or blood islands on the yolk were apparent within embryos. Erythrocytes were first evident in circulation near the completion of yolk absorption, c. $5 \mathrm{DAH}$, when larvae were $c .2 \cdot 0 \mathrm{~mm}$ notochord length $\left(L_{\mathrm{N}}\right)$. Erythrocyte abundance increased rapidly with larval development for $c .14$ to $16 \mathrm{DAH}$, then became highly variable following changes in cardiac chamber morphology and volume. Erythrocytic haemoglobin $(\mathrm{Hb})$ was not detected within whole larvae until they were $12 \mathrm{DAH}$ or $c .3 \cdot 1 \mathrm{~mm} L_{\mathrm{N}}$, well after yolk and oil-globule absorption. The $\mathrm{Hb}$ was not quantified until larvae were $>47$ DAH or $>7 \mathrm{~mm}$ standard length. The delayed appearance of erythrocytes and $\mathrm{Hb}$ in spot was similar to that reported for other marine fishes with small embryos and larvae. In oyster toadfish, a marine teleost that exhibits large embryos and larvae, the ICM and $\mathrm{Hb}$ were first evident in two bilateral slips of erythropoietic tissue in the embryos, $c .5$ days after fertilization. Soon thereafter, erythrocytes were evident in the heart, and peripheral and vitelline circulation. Initial haematopoiesis in oyster toadfish conformed with that described for zebrafish. While the genes that code for the development of haematopoiesis are conserved among vertebrates, gene
\end{abstract}

†Author to whom correspondence should be addressed. Tel.: +1 252728 8727; fax: +1 252728 8784; email: jeff.govoni@noaa.gov

$\$$ Present address: North Carolina State University, Department of Zoology, Box 7617, Raleigh, NC 27695, U.S.A.

TPresent address: University of Puerto Rico at Mayaguez, Department of Chemistry, National Institutes of Health Center of Biomedical Research Excellence in Protein Structure, Function and Dynamics, P. O. Box 9019, Calle Post 259 Norte, Mayaguez, PR 00681-9019, Puerto Rico.

$\dagger$ Present address: Carteret General Hospital, Medical Technology Laboratory, 3500 Arendell Street, Morehead City, NC 28557, U.S.A. 
expression lacks phylogenetic pattern among fishes and appears to conform more closely with phenotypic expression related to physiological and ecological influences of overall body size and environmental oxygen availability.

(C) 2005 The Fisheries Society of the British Isles (No claim to original US government works)

Key words: erythropoiesis; haemoglobin; ontogeny.

\section{INTRODUCTION}

The anatomical site of haematopoiesis changes with ontogeny and differs among classes of vertebrates. Current understanding is that the ontogenetic and phylogenetic plasticity in the site of initial haematopoiesis among vertebrates is due to to variable migration of stem cells derived from the embryonic mesoderm in the gastrula and neurula stages of embryos (Detrich et al., 1995). Primitive stem cells responsible for initial haematopoiesis first appear in the blood islands of the yolk-sac of most vertebrate embryos and produce distinct embryonic erythrocytes with globins (Zon, 1995). It is thought that some of these primitive erythropoietic stem cells die through apoptosis, while others migrate to the foetal or larval kidney, liver and spleen, where they become definitive erythroid, myeloid and lymphoid stem cells (Zon, 1995). In most adult vertebrates, erythropoiesis is confined to the spleen and bone marrow, though it can also occur in the genital organs, adrenal glands and the endocardium (Zon, 1995). Primitive stem cells produce foetal or larval haemoglobins $(\mathrm{Hb})$, while definitive stem cells produce advanced erythrocytes with different $\mathrm{Hb}$ (Zon, 1995).

The ontogeny of haematopoiesis in fishes differs from the generic vertebrate plan. Initial haematopoiesis occurs sooner in fishes than it does in mammals; some fishes produce $\mathrm{Hb}$ within $22 \mathrm{~h}$ after fertilization (HAF) and erythrocytes within 24 HAF, whereas mammals do so within 8-19 days (Thisse \& Zon, 2002). In zebrafish Danio rerio (Hamilton), and presumably most other teleostean species (Zon, 1995), haematopoiesis begins with embryonic, primitive stem cells that migrate from the mesoderm to the intermediate cell mass (ICM), bilateral slips of haematopoietic tissue within the dorso-lateral embryonic axis (Al-Adhami \& Kunz, 1977; Detrich et al., 1995). Erythroblasts develop therein the ICM and are released into the vitelline (yolk sac) and peripheral circulation within 24 HAF (Brownlie \& Zon, 1999). Within 4 days after fertilization (DAF), but still within the embryo, erythroblasts mature to embryonic erythrocytes that are replete with $\mathrm{Hb}$ (Brownlie \& Zon, 1999). After hatching and during early larval development (12 DAF), the site of haematopoiesis changes to the kidney and spleen (Brownlie \& Zon, 1999). Blood islands on the yolk sac, however, are apparent in a few fish embryos (Detrich et al., 1995), in some preceding, or developing concomitantly with the ICM (Iuchi \& Yamamoto, 1983).

The genes that code for the development of haematopoiesis are conserved among vertebrate classes (Zon, 1995) and may be conserved in teleosts as well, as indicated by zebrafish (Ransom et al., 1996; Weinstein et al., 1996). While zebrafish have become the accepted model for the development of many organ systems (Fishman, 2001), including the circulatory system and blood, there is 
variation in the site of initial $\mathrm{Hb}$ expression among the few other fishes so far examined (Colle-Vandevelde, 1963; Detrich et al., 1995), and this variation seemingly lacks phylogenetic pattern.

Spot Leiostomus xanthurus Lacepède is a perciform sciaenid of the temperate western North Atlantic Ocean. Spot are highly fecund and release small eggs, $c$. $0.8 \mathrm{~mm}$ in diameter, into the plankton (Powell \& Gordy, 1980). Eggs hatch in $c$. $48 \mathrm{~h}$ at $c .18$ to $22^{\circ} \mathrm{C}$, with newly hatched larvae 1.6 to $1.7 \mathrm{~mm}$ notochord length $\left(L_{\mathrm{N}}\right)$. Larvae that hatch from these small eggs develop slowly (Govoni, 1980); they reach metamorphosis $c .48$ days after hatching (DAH). Most visceral organs of spot are incompletely developed at hatching, become functional at the completion of yolk and oil-globule absorption, and complete development during metamorphosis to the adult body form (Govoni, 1980; Govoni \& Hoss, 2001).

Oyster toadfish Opsanus tau (L.), is a batrachoidiform fish also of the temperate western North Atlantic. Oyster toadfish spawn a small number of large adhesive eggs, c. 5.0 $\mathrm{mm}$ in diameter that are attached to nests (Dovel, 1960). Embryos and newly hatched larvae are large, $6 \cdot 0$ to $7 \cdot 0 \mathrm{~mm} L_{\mathrm{N}}$ (Tracy, 1926). Eggs hatch in 21 days at $20^{\circ} \mathrm{C}$ and larvae remain attached to the nest until the completion of yolk absorption in c. $24 \mathrm{DAH}$ at c. 18 to $22^{\circ} \mathrm{C}$ (Tracy, 1926). Visceral organ systems, including a circulation system, are well differentiated within embryos (Tracy, 1959).

This study (1) investigated the ontogeny of haematopoiesis in spot, (2) compared the site of initial $\mathrm{Hb}$ expression to that observed in the oyster toadfish and (3) compared haematopoiesis (specifically erythropoiesis) observed in spot and toadfish with the known and observed pattern for zebrafish within a context of ecological challenge and physiological performance.

\section{MATERIALS AND METHODS}

\section{SPECIMENS}

Brood stocks of spot were spawned and the eggs and larvae reared in the laboratory at 18 to $22^{\circ} \mathrm{C}$ following Hettler \& Powell (1981). Each day after fertilization, eggs were examined for their state of development. After the formation of the embryonic axis, the chorion was removed and fresh embryos treated histochemically for the presence of $\mathrm{Hb}$. Each day from hatching to metamorphosis, larvae were anaesthetized with tricaine methanesulphonate and examined live with a stereoscopic dissecting microscope for circulatory system development and for the presence of circulating erythrocytes. Some larvae were fixed in $10 \%$ neutral, phosphate-buffered formalin $(\mathrm{NBF})$ for histological preparation and some in 50/50 (volume/volume) $\mathrm{NBF} /$ acetone for histochemistry (NBF-acetone specimens were air dried before staining). Other larvae, from 11 to 47 $\mathrm{DAH}$, were frozen at $-70^{\circ} \mathrm{C}$ and stored for bulk assay of $\mathrm{Hb}$ (Table I). Fish $>47 \mathrm{DAH}$ or $>7.5 \mathrm{~mm}$ standard length $\left(L_{\mathrm{S}}\right)$ were captured in a tidal passage adjacent to Pivers Island, NC, U.S.A. $\left(34^{\circ} 43^{\prime} \mathrm{N} ; 76^{\circ} 40^{\prime} \mathrm{W}\right)$.

Brood stocks of oyster toadfish were spawned with a single male isolated with several females in tanks provided with suitable nest structure. Deposited eggs were incubated and larvae reared at 19 to $25^{\circ} \mathrm{C}$. Eggs and larvae were treated as with spot, except that a bulk assay for $\mathrm{Hb}$ was not attempted.

For comparison of observations made on spot and oyster toadfish, zebrafish were held in an aquarium at $27^{\circ} \mathrm{C}$ following Westerfield (1989). Eggs were collected from egg collection trays placed in the bottom of an aquarium. Embryos were treated histochemically as with spot for evidence of $\mathrm{Hb}$. 
TABLE I. Characteristics of bulk assays for haemoglobin in Leiostomus xanthurus

\begin{tabular}{lcccc}
\hline $\begin{array}{l}\text { Age } \\
\text { (days after hatching) }\end{array}$ & $\begin{array}{c}\text { Number of } \\
\text { larvae }\end{array}$ & $\begin{array}{c}\text { Mean } L_{\mathrm{N}} \\
\text { or } L_{\mathrm{S}} \\
(\mathrm{mm})\end{array}$ & $\begin{array}{c}\text { Estimated } * \\
\text { dry mass per larva } \\
(\mathrm{mg})\end{array}$ & $\begin{array}{c}\text { Estimated } \\
\text { total dry mass } \\
(\mathrm{mg})\end{array}$ \\
\hline 11 & 20 & $2 \cdot 81$ & $0 \cdot 030$ & $0 \cdot 600$ \\
12 & 20 & $3 \cdot 02$ & $0 \cdot 060$ & $1 \cdot 200$ \\
13 & 16 & $2 \cdot 80$ & $0 \cdot 065$ & $1 \cdot 000$ \\
19 & 20 & $3 \cdot 52$ & $0 \cdot 100$ & $1 \cdot 040$ \\
20 & 20 & $3 \cdot 69$ & $0 \cdot 100$ & $2 \cdot 000$ \\
21 & 20 & $3 \cdot 89$ & $0 \cdot 100$ & $2 \cdot 000$ \\
24 & 10 & $4 \cdot 33$ & $0 \cdot 350$ & $3 \cdot 500$ \\
25 & 10 & $4 \cdot 43$ & $0 \cdot 350$ & $3 \cdot 500$ \\
28 & 10 & $5 \cdot 34$ & $1 \cdot 400$ & $14 \cdot 000$ \\
31 & 11 & $6 \cdot 14$ & $1 \cdot 400$ & $14 \cdot 000$ \\
47 & 3 & $10 \cdot 89$ & $7 \cdot 000$ & $21 \cdot 000$ \\
\hline
\end{tabular}

*, Estimates of dry mass were taken from the regression of dry mass and notochord or standard length estimates that were given in Govoni et al. (1982).

\section{HISTOLOGY AND HISTOCHEMISTRY}

Spot and oyster toadfish embryos and larvae used for the examination for the presence of haematopoietic tissue and erythrocytes were dehydrated in ethanol and embedded in paraffin. Parasagittal histological sections $(5 \mu \mathrm{m})$ were cut and stained with Gill's haematoxylin and eosin $\mathrm{Y}$.

For histochemistry, embryos and larvae were stained in whole mount for 20 min with $1 \mathrm{ml}$ of $1 \%$ benzidine (Sigma, B-1883) in $1 \mathrm{M} \mathrm{CH}_{3} \mathrm{COOH}$, to which $20 \mu \mathrm{l}$ of $30 \% \mathrm{H}_{2} \mathrm{O}_{2}$ had been added. Benzidine applied with this method is a highly sensitive and specific $\mathrm{Hb}$ stain that renders a bright blue pigment: the only other reactants, catalase, horseradish peroxidase and haematin, render blue-green pigments (Broyles et al., 1979). Benzidine reacts with embryonic (Colle-Vandevelde, 1963), as well as larval and adult fish Hbs (Iuchi \& Yamagami, 1969).

\section{ERYTHROCYTE COUNTS AND MEASUREMENTS}

To estimate the rate of erythropoiesis, erythrocyte abundance (RBC) was estimated by counting erythrocytes in cardiac chambers. Standard methods of counting erythrocytes (Houston, 1990) in a haemocytometer or on blood smears or tissue squashes could not be used to estimate RBC, because of the small blood volume and low numbers of erythrocytes in circulation of developing fishes. Instead, erythrocytes in spot were counted in the median, sagittal, histological section through the atrium and ventricle of the heart (the serial section with the greatest height and width was taken as the median section through each cardiac chamber). A prolate spheroid approximated the shape of the atrium of spot larvae $\leq 9 \mathrm{DAH}$ and the ventricle of larvae $\leq 21$ DAH (Stainier, 2001); a regular tetrahedron approximated the shape of these cardiac chambers for older larvae (Farrell \& Jones, 1992). The RBC was estimated by dividing the number of erythrocytes in each cardiac chamber section by the volume of a $5 \mu \mathrm{m}$ median slice through either a spheroid or tetrahedron. After the formation of the ventricular spongiosum (Farrell \& Jones, 1992), counts of erythrocytes were taken from compartments within the spongiform ventricle and summed. Because a prolate spheroid approximated the shape of these compartments, volumes were taken as a slice through a spheroid and summed for the 
ventricle. The RBC after the formation of the spongiosum was estimated by dividing the summed counts and summed volumes. Cardiac-chamber dimensions were estimated with image analysis (Optimus).

The long and short axis of the cell membrane and the nucleus of 10 erythrocytes of a 5 DAH larva and a $25.3 \mathrm{~mm} L_{\mathrm{S}}$ juvenile of unknown age, measured with an ocular micrometer, provided estimates of erythrocyte cellular dimensions.

\section{HAEMOGLOBIN ASSAYS}

For bulk assay of $\mathrm{Hb}$, multiple specimens (Table I) were gently ground in a tissue

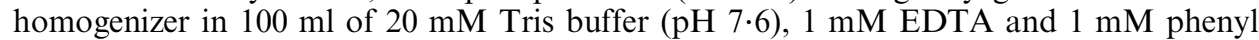
methyl sulphonyl fluoride (PMSF). The homogenate was centrifuged at $8000 \mathrm{~g}$ for $10 \mathrm{~min}$ to separate tissue and cellular debris. The volume of the supernatant was reduced to $40 \mu 1$ by evaporation in a stream of nitrogen, then brought to $60 \mu \mathrm{l}$ with Tris-EDTA-PMSF. This preparation was separated by electrophoresis on polyacrylamide gels with $125 \mathrm{~V}$ for $1.5 \mathrm{~h}$. Gels were cut in half; one half was stained with the benzidine-peroxide preparation for $20 \mathrm{~min}$ at $25^{\circ} \mathrm{C}$, while the other was stained with amido black (Puchtler et al., 1964) in $7 \cdot 5 \% \mathrm{CH}_{3} \mathrm{COOH}$ for $30 \mathrm{~min}$ (with this preparation, amido black served as a general protein stain). Benzidine stained gels were de-stained with three washes of deionized water; amido black stained gels were de-stained overnight in $7 \cdot 5 \% \mathrm{CH}_{3} \mathrm{COOH}$. The detection limits for $\mathrm{Hb}$ separated on polyacrylamide gels is $50 \mu \mathrm{g}$ (Broyles et al., 1979).

\section{RESULTS}

\section{SPOT}

Erythrocytes were not apparent within embryos and did not appear until well after hatching, at the completion of yolk absorption. In living larvae with stereomicroscopic magnification, the the heart was beating at hatching with a few, apparently colourless corpuscles, unidentifiable to cell-type, in circulation in the dorsal aorta and caudal vein as the yolk was exhausted and a remnant of the oil globule remained. These larvae were from 4 to $7 \mathrm{DAH}$ or from $2 \cdot 0$ to $2 \cdot 5 \mathrm{~mm}$ $\left(L_{\mathrm{N}}\right)$ (Fyhn \& Govoni, 1995). Noticeable redness in the cardiac and gill arch region was seen in larvae at c. $20 \mathrm{DAH}$.

An ICM was not evident within embryos. Haematopoietic tissue and erythrocytes were first seen in the head kidney of larvae 3 DAH [Fig. 1(a)]. Erythrocytes were first seen in circulation $5 \mathrm{DAH}$ [Fig. 1(b)]. At $11 \mathrm{DAH}$, haematopoietic tissue appeared in the spleen [Fig. 1(c)].

Benzidine reactions within whole mounts were not evident in embryos [Fig. 2(a)]. Melanocytes were evident within the integument covering the cranium and dorso-lateral flanks of embryos, but no benzidine reactions indicating either an ICM or blood islands on the yolk were evident [Fig. 2(a)]. Benzidine reactions were first seen in larval tissues $12 \mathrm{DAH}$, or $3.1 \mathrm{~mm} L_{\mathrm{N}}$ [Fig. 3(a)]. Reactions intensified with the age of larvae with bright blue reaction products concentrated in the heart, the gill filaments and the mesencephalon of the brain [Fig. 3(b)]. The gut contents of larvae $10 \mathrm{DAH}$ or $2.7 \mathrm{~mm} L_{\mathrm{N}}$ that had fed on the rotifer Brachionus plicatilis also stained with benzidine [Fig. 3(b)]. In specimens $>20 \mathrm{DAH}$, and $>3.8 \mathrm{~mm}$ $L_{\mathrm{N}}$, blue staining tended to be ubiquitous throughout larvae, except in the caudal region. Bulk assays for $\mathrm{Hb}$ did not produce detectable quantities of 

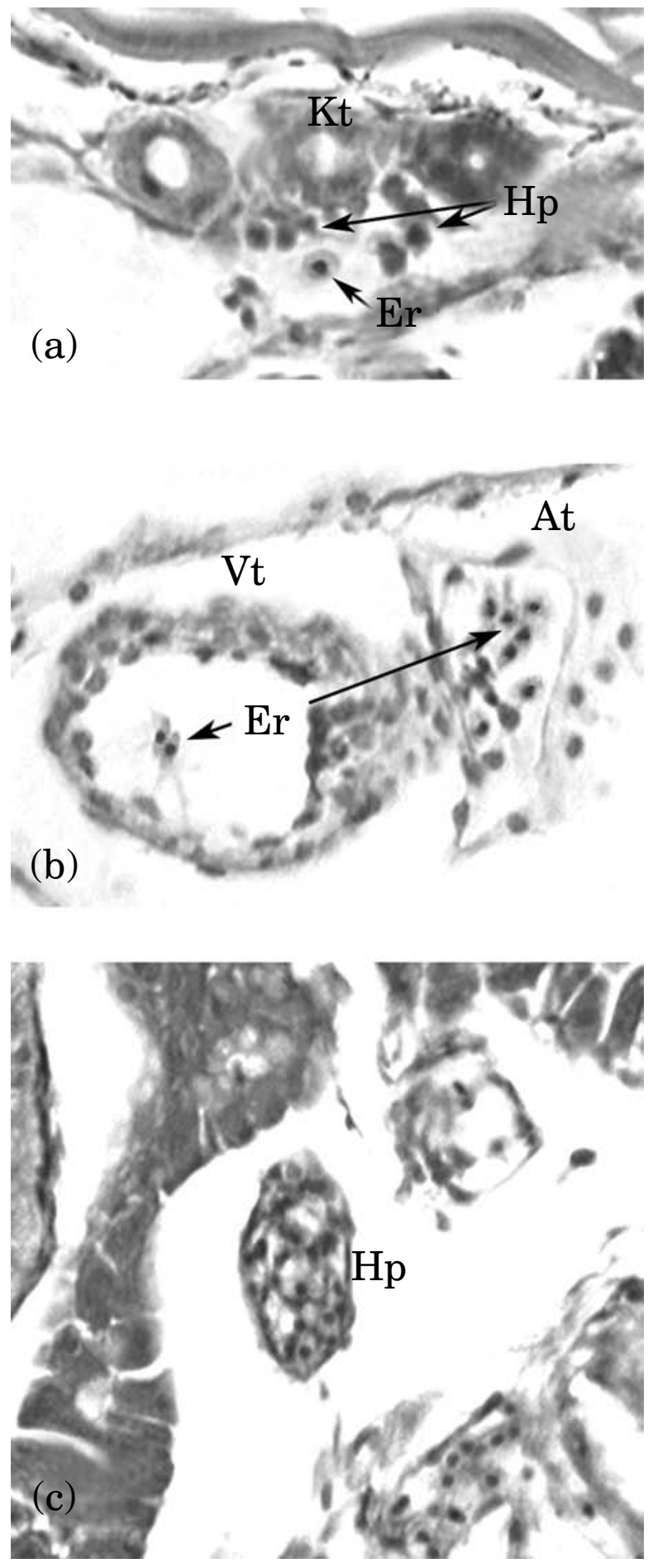

FIG. 1. (a) Erythrocytes (Er) and haematopoietic tissue (Hp) in head kidney (Kt, kidney tubules) of a larval Leiostomus xanthurus 3 days after hatching (DAH), (b) erythrocytes in the atrium (At) and ventricle $(\mathrm{Vt})$ of a $5 \mathrm{DAH}$ larva and (c) haematopoietic tissue in the spleen of a 11 DAH larva. 

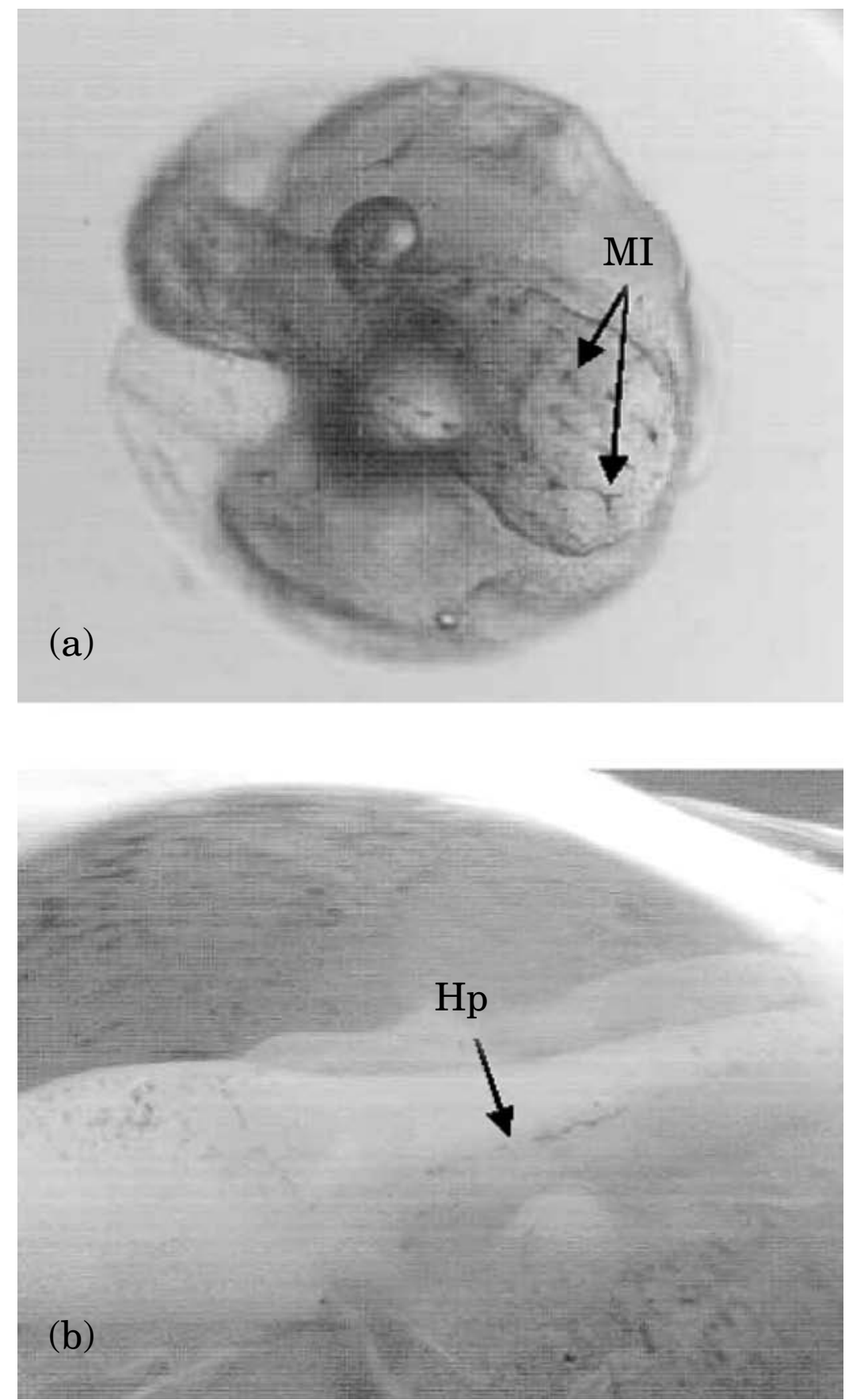

FIG. 2. Whole mounts of embryos stained with benzidine. (a) Leiostomus xanthurus embryo, $48 \mathrm{~h}$ after fertilization (Ml, melanophores) and (b) an Opsanus tau embryo 5 days after fertilization (Hp, haematopoietic tissue). 

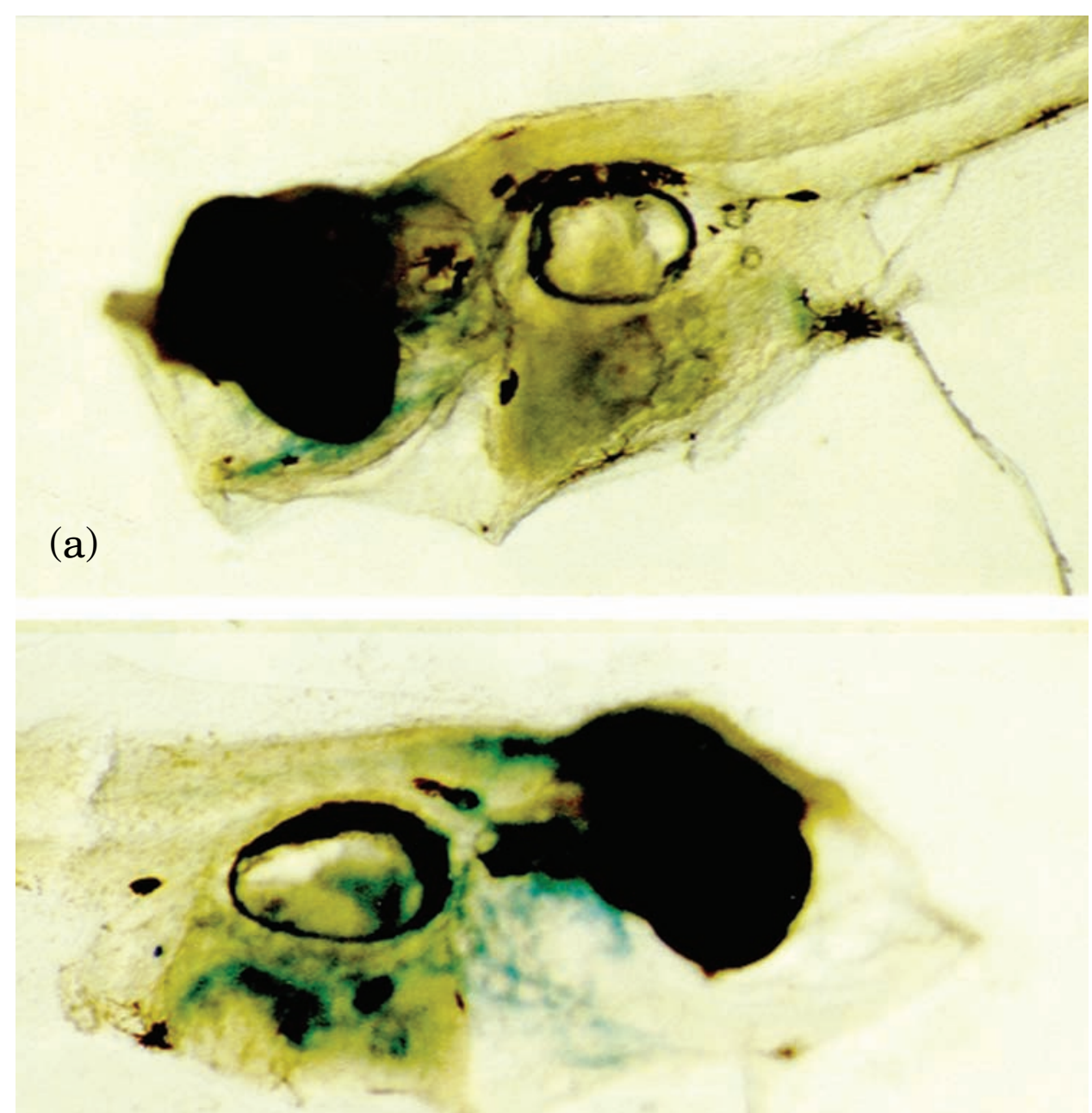

(b)

FIG. 3. Whole mounts of Leiostomus xanthurus stained with benzidine (bright blue indicates haemoglobin): (a) a larva 1 day after hatching and (b) a larva 15 days after hatching.

$\mathrm{Hb}$ in larvae as old as $47 \mathrm{DAH}$ or $11 \mathrm{~mm} L_{\mathrm{N}}$ and with a combined dry mass of $154 \mathrm{mg}$.

The RBC increased rapidly for the first 10 to 12 DAH (Fig. 4), then became static and highly variable (Fig. 4), at abundances characteristic of adults (Cameron, 1970). Variation in RBC increased after changes in cardiac chamber shape (9 DAH for the atrium; $21 \mathrm{DAH}$ for the ventricle), structure (formation of the ventricular spongiosum after $25 \mathrm{DAH}$ ) and consequent volume (Fig. 5). The $\mathrm{RBC}$ in the atrium after $12 \mathrm{DAH}$ ranged from $1.55 \times 10^{6}$ to $8.48 \times 10^{6}$ cells $\mathrm{mm}^{-3}$ : the $\mathrm{RBC}$ in the ventricle after $12 \mathrm{DAH}$ ranged from $5.87 \times 10^{6}$ to $1.21 \times 10^{5}$ cells $\mathrm{mm}^{-3}$. The difference in $\mathrm{RBC}$ estimates between the atrium 


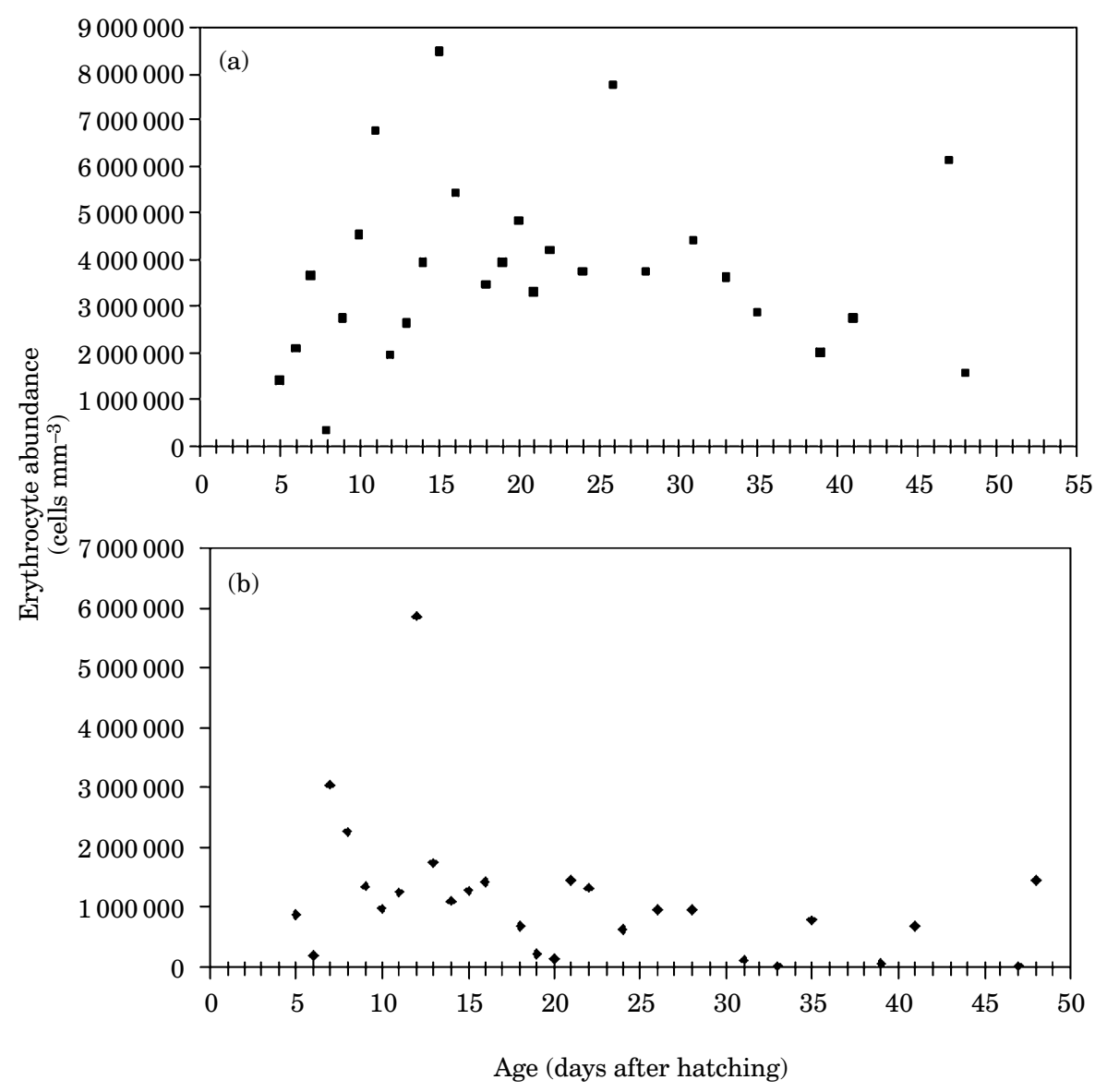

FIG. 4. Erythrocyte abundance in (a) the atrium and (b) the ventricle of larval Leiostomus xanthurus of various ages.

and ventricle does not reflect a real difference in haematocrit (Hct); this difference is an artifact that owes either to the difference in the assumed solid geometrical shapes used to approximate the form of the atrium and ventricle and consequent bias in estimated chamber volume, or to differences in the time of fixation during the cardiac contraction cycle, i.e. end-systole, end-diastole or somewhere in between. The Hct, approximated from erythrocyte cell areas and the area of cardiac chamber of a 22 DAH larva, was $26 \%$ in the atrium and $47 \%$ in the ventricle.

Erythrocyte cellular dimensions differed between larvae and juveniles (Table II). Histologically identifiable erythrocytes of juveniles (long axis mean, $6.51 \mu \mathrm{m})$ were significantly longer $(t$ test, d.f. $=9, P>0.0063)$ than were the erythrocytes of larvae $($ mean $=5.67 \mu \mathrm{m})$. The nuclei of the erythrocytes of larvae (short axis mean $=2.94 \mu \mathrm{m})$ were significantly wider $(P>0.0368)$ than were the nuclei of the juvenile (mean $=2 \cdot 10 \mu \mathrm{m}$ ). 


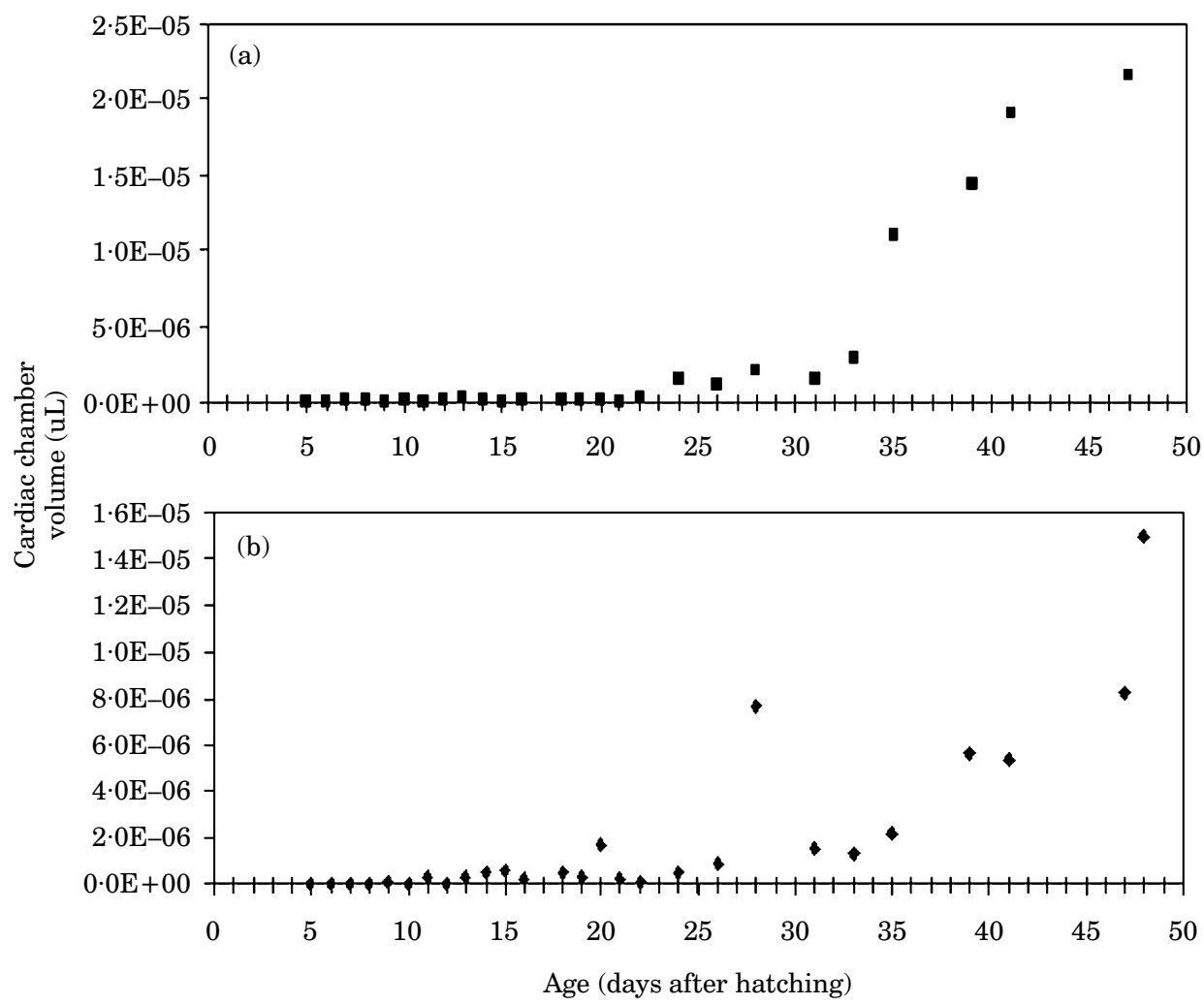

FIG. 5. (a) Atrial and (b) ventricular volumes of larval Leiostomus xanthurus of various ages.

\section{OYSTER TOADFISH}

In oyster toadfish, $\mathrm{Hb}$ was first evident in two dorso-bilateral slips of tissue, the ICM, within embryos after the formation of the embryonic axis and eye buds [Fig. 2(b)], c. 5 DAF. Erythrocytes were evident soon after in embryonic circulation within the beating heart and the descending vitelline artery, ascending

TABLE II. Cellular dimensions (mean \pm 2 s.E., $n=10$ ) of erythrocytes in larval and juvenile Leiostomus xanthurus

\begin{tabular}{|c|c|c|c|c|c|c|}
\hline \multirow[b]{2}{*}{ Stage } & \multirow{2}{*}{$\begin{array}{c}\text { Age } \\
\text { (days after } \\
\text { hatching) }\end{array}$} & \multirow[b]{2}{*}{$\begin{array}{l}\text { Length } \\
(\mathrm{mm})\end{array}$} & \multicolumn{2}{|c|}{$\begin{array}{c}\text { Cell } \\
\text { membrane }\end{array}$} & \multicolumn{2}{|c|}{ Nucleus } \\
\hline & & & $\begin{array}{l}\text { Long axis } \\
\qquad(\mu \mathrm{m})\end{array}$ & $\begin{array}{l}\text { Short axis } \\
\quad(\mu \mathrm{m})\end{array}$ & $\begin{array}{l}\text { Long axis } \\
\qquad(\mu \mathrm{m})\end{array}$ & $\begin{array}{l}\text { Short axis } \\
\qquad(\mu \mathrm{m})\end{array}$ \\
\hline Larval & 5 & $2 \cdot 0$ & $5 \cdot 67 \pm 0 \cdot 40$ & $4 \cdot 36 \pm 0 \cdot 72$ & $2 \cdot 31 \pm 0 \cdot 36$ & $2.73 \pm 0.78$ \\
\hline Juvenile & & $25 \cdot 3$ & $7 \cdot 35 \pm 0 \cdot 40$ & $4 \cdot 83 \pm 0 \cdot 80$ & $2 \cdot 10 \pm 0 \cdot 00$ & $2 \cdot 63 \pm 0.86$ \\
\hline
\end{tabular}


vitelline vein, and caudal artery and vein. The RBC was static and variable from hatching and throughout larval development.

\section{ZEBRAFISH}

Zebrafish embryos had a well differentiated, beating heart and erythrocytes in well differentiated vitelline and peripheral circulatory vessels at $18 \mathrm{HAF}$. The ICM was evident with benzidine staining in the pharyngula stage (Dahm, 2002) at c. $24 \mathrm{HAF}$.

\section{DISCUSSION}

Benzidine (Al-Adhami \& Kunz, 1977; Iuchi \& Yamamoto, 1983), or its biphenyl relative dianisidine (Detrich et al., 1995), have identified $\mathrm{Hb}$ expression in the ICM and blood islands of fish embryos. Expression of early markers of haematopoietic tissue (markers of the GATA1 and GATA2 genes) have also demonstrated the ICM (Detrich et al., 1995; Brownlie \& Zon, 1999). Whereas only benzidine was used in the present study to demonstrate $\mathrm{Hb}$ expression, the ICM or blood islands would have been evident with this procedure. An ICM was not evident in spot; it was in oyster toadfish and zebrafish.

Embryonic, larval and adult erythrocytes differ in cytological structure as well as cellular dimensions (Iuchi, 1973a; Lane et al., 1982). Cellular dimensions, measured in histological sections of larval and juvenile spot were considerably smaller than were the dimensions of other adult sciaenids measured from blood smears (Saunders, 1966). Dimensions of cells measured here and those reported by Saunders (1966), differ probably because of artifacts of fixation and histological preparation. Erythrocytes of larval spot, with narrow cytoplasm and larger and rounder nuclei, resembled the transitional erythrocytes of larval rainbow trout Oncorhynchus mykiss (Walbaum) found in the kidney and spleen during the transition from embryonic to juvenile haematopoiesis (Iuchi \& Yamamoto, 1983).

The ontogeny of haematopoiesis in the marine fish spot is clearly different than it is in another marine fish, oyster toadfish, where haematopoiesis is more like that of the freshwater zebrafish. In spot, erythropoiesis begins not in the embryo, but in the larva at the completion of yolk absorption. The site of initial erythropoiesis observed in spot differs from that observed in oyster toadfish, as well as that reported for (Brownlie \& Zon, 1999), and observed here in zebrafish. In spot, haematopoietic tissue is first seen in the head kidney: later in larval development, erythropoiesis shifts to the spleen. Embryos and yolk-sac larvae of spot have no circulating erythrocytes. Erythrocytes appear at yolk absorption and increase in abundance with larval growth and development, until 14 to 16 DAH, when RBC reaches adult levels (Cameron, 1970). Erythrocytes become abundant enough to register benzidine reactions about midway through the larval development of spot, c. 15 DAH. While undoubtably present in larval spot erythrocytes, $\mathrm{Hb}$ is not present in measurable quantities until after metamorphosis. In oyster toadfish and zebrafish, erythrocytes are released into circulation from the ICM, and become abundant in vitelline and peripheral circulation of embryos and yolk-sac larvae. 
The conspicuous lack of phylogenetic pattern in the expression of genes that code for initial haematopoiesis has been tentatively explained by differences in the migration of mesoderm destined to become primitive haematopoietic stem cells (Detrich et al., 1995). Detrich et al. (1995) hypothesized two modes of migration: mesoderm that originates in the embryonic caudal region, migrates either to the ICM or to blood islands on the yolk. Detrich et al. (1995) further hypothesized that the difference in migratory pathways might be due to varying rates of epiboly, gastrulation and neurula formation within the embryo. The teleosts so far examined: zebrafish, a cypriniform, killifish Fundulus spp., a cyprinodontiform (Detrich et al., 1995), oyster toadfish, a batrachoidiform, and angelfish Pterophyllum scalare (Lichtenstein) (Detrich et al., 1995) and spot, both perciforms, span a broad range of phylogeny and register differing sites of initial erythropoiesis.

If phylogeny does not explain differences in the site of initial erythropoiesis, rates of embryonic development along with the physiological and ecological demands on fish larvae might explain differences in phenotypic gene expression (Hatle, 2004) for early haematopoiesis. Rates of embryological development are correlated with embryonic size. Size of embryos is a factor in oxygen diffusion and internal convection.

The phylogenetic diversity of fishes makes it difficult, if not impossible, to appropriately categorize their ontogeny; yet the ontogeny of teleosts tends to follow morphological, physiological and ecological trends of inferred adaptations to spawning habitat and developmental rate (Balon, 1981). This trend is a continuum of generic developmental progress among fishes that is predicated on the timing of developmental events including the onset of organ system development, and is correlated with embryonic size (Govoni, 2004). Broadcast spawners of high fecundity typically have small, rapidly developing eggs, and slowly developing embryos and larvae with organ systems that are undifferentiated or unelaborated at hatching (Balon, 1981). Substratum, or nest-spawners, of low fecundity typically have large eggs and slowly developing embryos and larvae with well differentiated organ systems at hatching (Balon, 1981). With its high fecundity, small embryonic and larval size, and incompletely developed larval visceral organs at hatching, spot is near one end of this continuum. With its low fecundity, large embryonic and larval size, and well developed embryonic organ systems at hatching, the development of oyster toadfish is near the opposite end. Zebrafish produce demersal eggs of intermediate size, c. $1.2 \mathrm{~mm}$ in diameter, with rapidly developing embryos and larvae; newly hatched larvae are $c .3 .5 \mathrm{~mm}$ $L_{\mathrm{N}}$ (Dahm, 2002; Schilling, 2002). Because of the abundance of erythrocytes in embryos and larvae, the well developed vitelline circulation, and differentiated visceral organ systems in embryos (Chen et al., 1996; Pack et al., 1996; Schilling, 2002), zebrafish are along this hypothetical continuum.

Balon (1975) identified two principal ecological factors that shape the evolution of reproductive modes and development of fishes: predation and oxygen availability. Apparent specializations that provide for oxygen acquisition and internal convection are shown as modifications of the developing gills and circulatory system, and possibly the appearance of $\mathrm{Hb}$. Many large fish embryos and larvae have well developed vitelline and peripheral circulatory systems, and functional gills that accomplish the exchange and internal convection of oxygen (Balon, 1975; Rombough, 2004). In small larval fishes, oxygen diffuses through 
the integument; tissues are perfused with fluids laden with oxygen within the fin fold or yolk sac, or in plasma transiting through a rudimentary circulatory system (O'Connell, 1981).

The ontogenetic shift from diffusion of oxygen across the integument to diffusion across gill lamellae, and from perfusion through plasma and tissues to erythrocytic convection within the circulatory system, might be due to a threshold in the ratio of surface area of the integument to internal volume (Rombough, 2004). Surface area increases by the power of two; volume by the power of three. Therefore, a fish larva that doubles its size should require an approximate eightfold increase in oxygen diffusion. Moreover, metabolic oxygen demand increases more rapidly with larval growth than does surface area (Rombough, 2004). Using ambient dissolved oxygen, diffusion of oxygen through fish tissue, and metabolic demand for oxygen (at $20^{\circ} \mathrm{C}$ ), Kranenberg et al. (2000) calculated that a threshold in surface to volume ratio could not be invoked to explain the onset of the circulatory system in fish embryos and larvae. Kranenberg et al. (2000), however, did not consider haematopoiesis and the functional role of erythrocytes and $\mathrm{Hb}$ specifically. Surface to volume ratios not only change ontogenetically, but differ between large and small larvae.

If surface to volume ratio cannot explain the development of a circulatory system, can it explain the difference in early haematopoiesis among fishes with large and small embryos? The physiological evidence is conflicting.

The physiological performance of large and small embryos and larvae that is dependent upon oxygen differs, but the evidence is equivocal. The level at which oxygen limits metabolic rates increases during embryonic development and reaches a maximum at hatching before declining in the freshwater zebrafish (Rombough, 2004). In contrast, critically limiting, oxygen partial pressures are high throughout the larval period of the marine herring Clupea harengus L. and plaice Pleuronectes platessa L., fishes with small embryos and larvae, and does not decline until after metamorphosis (De Silva \& Tytler, 1972). In larval rainbow trout, a species with large embryos and larvae, the heart and respiratory rate increase with exposure to hypoxic water or when $\mathrm{Hb}$ was ablated with carbon monoxide (Holeton, 1971), whereas little change in oxygen consumption, heart rate, blood pressure and swimbladder inflation was evident when the embryonic and larval $\mathrm{Hb}$ of zebrafish was ablated with carbon monoxide or phenylhydrazine (Pelster \& Burggren, 1996). The observations of Pelster \& Burggren (1996) contrast sharply with the condition of mutant zebrafish, whose embryonic or larval erythrocytes show weak diaminofluorene reaction to $\mathrm{Hb}$ and poor swimbladder inflation (Weinstein et al., 1996). The description of initial haematopoiesis provided by Weinstein et al. (1996), however, might indicate that primitive embryonic $\mathrm{Hb}$ contributes only marginally to the internal convection of oxygen. Spot larvae at the completion of yolk absorption, are fully capable of secreting gas into the swimbladder against a pressure of 1 ATM without the benefit of the multiplication of partial gas pressure within the blood by an organized rete mirabile, which does not develop until the onset of metamorphosis (Govoni \& Hoss, 2001), and without abundant erythrocytes and measurable quantities of $\mathrm{Hb}$. The ability of larval spot to perform various physiological functions without measurable quantities of $\mathrm{Hb}$ is not unusual; some adult fishes, particularly the Antarctic icefishes, Channichyidae, are also 
able to accomplish physiological functions that require oxygen without the benefit of $\mathrm{Hb}$ (Feller \& Gerday, 1997), or when the capacity of $\mathrm{Hb}$ to bind oxygen has been ablated (Holeton, 1972), particularly when these fishes are in well oxygenated water. The physiological evidence for the function of $\mathrm{Hb}$ in relation to embryonic, larval or even adult size is confounding.

Embryonic and larval $\mathrm{Hb}$ differs in molecular structure and possibly function (Jensen et al., 1998). Primitive stem cells produce embryonic Hb; definitive stem cells produce larval or adult $\mathrm{Hb}$ (Zon, 1995). Different larval and adult Hbs have been demonstrated in rainbow trout (Iuchi \& Yamagami, 1969; Iuchi, 1973b; Iuchi \& Yamamoto, 1983), brook trout, Salvelinus fontinalis (Mitchill), and salmonid hybrids (Iuchi et al., 1975), all fishes with relatively large embryos and larvae. Different $\mathrm{Hb}$ has not been demonstrated for the ontogeny of fishes other than the salmonids and zebrafish, though the structure and function of adult $\mathrm{Hb}$ of spot has been determined (Bonaventura et al., 1976; Mylvaganam et al., 1996).

Erythrocytes, when they appear in fishes with small embryos and larvae, have been reported as not being well invested with $\mathrm{Hb}$ (De Silva, 1974; Hickey, 1982; Blaxter, 1988; Rombough, 1988). De Silva (1974) hypothesized that erythrocytic myoglobin $(\mathrm{Mb})$ might serve to transport oxygen, while El-Fiky \& Wieser (1988) suggested that muscle $\mathrm{Mb}$ stores and transports oxygen in larval fishes. Balon (1975) speculated that, carotenoid pigments not associated with erythrocytes, may substitute for $\mathrm{Hb}$ in storing and transporting oxygen. The oxygen storing and transporting functions of $\mathrm{Mb}$ are credible, but these functions for carotenoids are improbable. The $\mathrm{Mb}$ serves to supplement or substitute for $\mathrm{Hb}$ in the Antarctic icefishes (O’Brien \& Sidell, 2000). Embryonic or larval Hb may simply be a functionally unnecessary anlage, as is the embryonic beating heart (Burggren, 2004).

The ontogeny of haematopoiesis in the perciform fish, spot, differs from that reported as the norm for fishes (Zon, 1995). Neither an ICM, nor blood islands, were evident in embryos. The delayed appearance of erythrocytes and $\mathrm{Hb}$ in spot is similar to that reported for three other marine fishes (De Silva, 1974; Morrison, 1993) with small embryos and larvae. Erythrocytes develop toward the end of the yolk-sac period within the head kidney, and it is probable that these larval erythrocytes are invested with $\mathrm{Hb}$, though not in detectable quantities, until later in the larval period.

While the genes that code for haematopoiesis are conserved among fishes (Ransom et al., 1996; Weinstein et al., 1996), phenotypic gene expression lacks phylogenetic pattern. The parsimonious explanation for this observation is phenotypic plasticity of gene expression as influenced by the physiological and ecological contraints of overall body size and oxygen availability. There is emerging evidence of oxygen induced alterations in gene expression within species of fishes (Gracey et al., 2001).

Treatment of fishes conformed with guidelines of the American Fisheries Society in agreement with the American Society of Ichthyologists and Herpetologists and the American Institute of Fishery Research Biologists (www.fisheries.org). J. Bonaventura was supported by the U. S. National Institutes of Health Grant 5 P20 RP016439-04. We thank J.S. Burke and J.A. Morris (NOAA), who spawned fishes and reared larvae in the laboratory. P.A. Tester, R.W. Litaker, M. Vandersea and D.W. Engel (NOAA) reviewed early drafts of the manuscript. The United States government has the right to retain a nonexclusive, royalty-free license in and to any copyright covering this paper. 


\section{References}

Al-Adhami, M. A. \& Kunz, Y. Q. (1977). Ontogenesis of hematopoietic sites in Brachydanio rerio. Development, Growth, and Differentiation 19, 171-179.

Balon, E. K. (1975). Reproductive guilds of fishes: a proposal and definition. Journal of the Fisheries Research Board of Canada 32, 821-864.

Balon, E. K. (1981). Saltatory processes and altricial to precocial forms in the ontogeny of fishes. American Zoologist 21, 573-596.

Blaxter, J. H. S. (1988). Pattern and variety in development. In Fish Physiology, Vol. XI (Hoar, W. S. \& Randall, D. J., eds), pp. 1-58. New York: Academic Press.

Bonaventura, C., Sullivan, B. \& Bonaventura, J. (1976). Spot hemoglobin: studies on the root effect hemoglobin of a marine teleost. Journal of Biological Chemistry 251, 1871-1876.

Brownlie, A. \& Zon, L. (1999). The zebrafish as a model system for the study of haematopoiesis. BioScience 49, 382-392.

Broyles, R. H., Pack, B. M., Berger, S. \& Dorn, A. R. (1979). Quantification of small amounts of hemoglobin in polyacrylamide gels with benzidine. Analytical Biochemistry 94, 211-219.

Burggren, W. W. (2004). What is the purpose of the embryonic heart rate? or how facts can ultimately prevail over physiological dogma. Physiological and Biochemical Zoology 77, 333-345.

Cameron, J. M. (1970). Blood characteristics of some marine fishes of the Texas Gulf coast. Texas Journal of Science 21, 275-283.

Chen, J.-N., Haffter, P., Odenthal, J., Vogelsang, E., Brand, M., van Eeden, F. J. M., Furutani-Seiki, M., Granato, M., Hammerschmidt, M., Heisenberg, C.-P., Jiang, Y.-J., Kane, D. A., Kelsh, R. N., Mullins, M. C. \& Nüsslein-Volhard, C. (1996). Mutations affecting the cardiovascular system and other internal organs in zebrafish. Development 123, 293-302.

Colle-Vandevelde, A. (1963). Blood anlage in teleostei. Nature 198, 1223.

Dahm, R. (2002). Atlas of embryonic stages of development in the zebrafish. In Zebrafish: a Practical Approach (Nüsslein-Volhard, C. \& Dahm, R., eds), pp. 219-236. Oxford: Oxford University Press.

De Silva, C. (1974). Development of the respiratory system in herring and plaice larvae. In The Early Life History of Fishes (Blaxter, J. H. S., ed.), pp. 465-485. London: Springer-Verlag.

De Silva, C. D. \& Tytler, P. (1972). The influence of reduced environmental oxygen on the metabolism and survival of herring and plaice larvae. Netherlands Journal of Sea Research 7, 345-362.

Detrich, H. W., Kieran, M. W., Chan, F. Y., Barone, L. M., Yee, K., Rundstadler, J. A., Pratt, S., Ransom, D. \& Zon, L. I. (1995). Intraembryonic hematopoietic cell migration during vertebrate development. Proceedings of the National Academy of Sciences 92, 10713-10717.

Dovel, W. (1960). Larval development of the oyster toadfish, Opsanus tau. Chesapeake Science 1, 187-195.

El-Fiky, N. \& Wieser, W. (1988). Life styles and patterns of development of gills and muscles in larval cprinids (Cyprinidae; Teleostei). Journal of Fish Biology 33, 135-145.

Farrell, A. P. \& Jones, D. R. (1992). The heart. In Fish Physiology, Vol. XIIA (Hoar, W. S., Randall, D. J. \& Farrell, A. P., eds), pp. 1-88. New York: Academic Press.

Feller, G. \& Gerday, C. (1997). Adaptations of the hemoglobinless antarctic icefish (Channichthyidae) to hypoxia tolerance. Comparative Biochemistry and Phsyiology 118, 981-987.

Fishman, M. C. (2001). Zebrafish - the canonical vertebrate. Science 294, 1290-1291.

Fyhn, H. J. \& Govoni, J. J. (1995). Endogenous nutrient mobilization during egg and larval development in two marine fishes - Atlantic menhaden and spot. ICES Marine Science Symposium 201, 64-69. 
Govoni, J. J. (1980). Morphological, histological and functional aspects of alimentary canal and associated organ development in larval Leiostomus xanthurus. Review Canadien de Biologie 39, 669-680.

Govoni, J. J. (2004). Epilogue. In The Development of Form and Function in Fishes and the Question of Larval Adaptation (Govoni, J. J., ed.), pp. 195-198. American Fisheries Society Symposium $\mathbf{4 0 .}$

Govoni, J. J. \& Hoss, D. E. (2001). Comparison of the development and function of the swimbladder of Brevoortia tyrannus (Clupeidae) and Leiostomus xanthurus (Sciaenidae). Copeia 2001, 430-442.

Govoni, J. J., Peters, D. S. \& Merriner, J. V. (1982). Carbon assimilation during larval development of the marine teleost Leiostomus xanthurus Lacepède. Journal of Experimental Marine Biology and Ecology 64, 287-299.

Gracey, A. Y., Troll, J. V. \& Somero, G. N. (2001). Hypoxia-induced gene expression profiling in the euryoxic fish Gillichthys mirabilis. Proceedings of the National Academy of Sciences 98, 1993-1998.

Hatle, J. D. (2004). Physiology underlaying phenotypic plasticity and polyphenisms: introduction to the symposium. Integrative and Comparative Biology 42, 605-606.

Hettler, W. F. \& Powell, A. B. (1981). Egg and larval fish production at the NMFS Beaufort Laboratory, N.C., USA. Rapports et Procès-verbaux des Réunions Conseil International pour l'Exploration de la Mer 178, 501-503.

Hickey, G. M. (1982). Wound healing in fish larvae. Journal of Experimental Marine Biology and Ecology 57, 149-168.

Holeton, G. F. (1971) Respiratory and circulatory responses of rainbow trout larvae to carbon monoxide and to hypoxia. Journal of Experimental Biology 55, 683-694.

Holeton, G. R. (1972). Gas exchange in fish with and without hemoglobin. Respiratory Physiology 14, 142-150.

Houston, A. H. (1990). Blood and circulation. In Methods for Fish Biology (Schreck, C. B. \& Moyle, P. B., eds), pp. 273-334. Bethesda, MD: American Fisheries Society.

Iuchi, I. (1973a). The post-hatching transition of erythrocytes from larval to adult type in the rainbow trout, Salmo gairdnerii irideus. Journal of Experimental Zoology 184, 383-396.

Iuchi, I. (1973b). Chemical and physiological properties of the larval and the adult hemoglobins in rainbow trout, Salmo gairdneri irideus. Comparative Biochemistry and Physiology 44B, 1087-1101.

Iuchi, I. \& Yamagami, M. (1969). Electrophoretic patterns of larval haemoglobins of the salmonid fish, Salmo gairdneri irideus. Comparative Biochemistry and Physiology 28, 977-979.

Iuchi, I. \& Yamamoto, M. (1983). Erythropoiesis in the developing rainbow trout, Salmo gairdneri irideus: histochemical and immunochemical detection of erythropoietic organs. Journal of Experimental Zoology 226, 409-417.

Iuchi, I., Suzuki, R. \& Yamagami, K. (1975). Ontogenetic expression of larval and adult hemoglobin phenotypes in the intergeneric salmonid hybrids. Ontogenetic expression of larval and adult hemoglobin phenotypes in the intergeneric salmonid hybrids. Journal of Experimental Zoology 192, 57-64.

Jensen, F. B., Fago, F. \& Weber, R. E. (1998). Hemoglobin structure and function. In Fish Physiology: Fish Respiration, Vol. XVII (Perry, S. F. \& Tufts, B. L., eds), pp. 1-58. New York: Academic Press.

Kranenberg, S., Muller, M., Grielen, J. L. W. \& Verhagen, J. H. G. (2000). Physical constraints on body size in teleost embryos. Journal of Theoretical Biology 204, 113-133.

Lane, H. C., Weaver, J. W., Benson, J. A. \& Nichols, H. A. (1982). Some age related changes of adult rainbow trout, Salmo gairdneri Rich., peripheral erythrocytes separated by velocity sedimentation at unit gravity. Journal of Fish Biology 21, 1-13.

Morrison, C. M. (1993). Histology of the Atlantic cod, Gadus morhua. Part Four. Eleutheroembryo and larva. Canadian Special Publication of Fisheries and Aquatic Sciences 119. 
Mylvaganam, S. E., Bonaventura, C., Bonaventura, J. \& Getzoff, E. D. (1996). Structural basis for the Root effect in haemoglobin. Nature Structural Biology 3, 275-283.

O'Brien, K. M. \& Sidell, B. D. (2000). The interplay among cardiac ultrastructure, metabolism, and the expression of oxygen-binding proteins in Antarctic fishes. Journal of Experimental Biology 203, 1287-1297.

O'Connell, C. P. (1981). Development of organ systems in the northern anchovy Engraulis mordax, and other teleosts. American Zoologist 21, 29-46.

Pack, M., Solnica-Krezel, L., Malicki, J., Neuhauss, S. C. F., Schier, A. F., Stemple, D. K., Driever, W. \& Fishman, M. C. (1996). Mutations affecting development of zebrafish digestive organs. Development 123, 321-328.

Pelster, B. \& Burggren, W. W. (1996). Disruption of hemoglobin oxygen transport does not impact oxygen-dependent physiological processes in developing embryos of zebrafish (Danio rerio). Circulation Research 79, 358-362.

Powell, A. B. \& Gordy, H. R. (1980). Egg and larval development of the spot, Leiostomus xanthurus (Sciaenidae). Fisheries Bulletin 78, 701-714.

Puchtler, H., Rosenthal, S. I. \& Sweat, F. (1964). Revision of the amido black stain for hemoglobin. Archives of Pathology 78, 76-78.

Rombough, P. J. (1988). Respiratory gas exchange, aerobic metabolism, and effects of hypoxia during early life. In Fish Physology, Vol. XI (Hoar, W. S. \& Randall, D. R., eds), pp. 59-161. New York: Academic Press.

Rombough, P. J. (2004). Structural and functional development of the larval gill. In The Development of Form and Function in Fishes and the Question of Larval Adaptation (Govoni, J. J., ed.), pp. 47-83. American Fisheries Society Symposium 40.

Ransom, D. G., Haffter, P., Odenthal, J., Brownlie, A., Vogelsang, E., Kelsh, R. N., Brand, M., van Eeden, F. J. M., Furutani-Seiki, M., Granato, M., Hammerschmidt, M., Heisenberg, C.-P., Jiang, Y.-J., Kane, D. A., Mullins, M. C. \& Nüsslein-Volhard, C. (1996). Characterization of zebrafish mutants with defects in embryonic haematopoiesis. Development 123, 311-319.

Saunders, D. C. (1966). Differential blood cell counts of 121 species of marine fishes of Puerto Rico. Transactions of the American Microscopical Society 85, 427-449.

Schilling, T. F. (2002). The morphology of larval and adult zebrafish. In Zebrafish: a Practical Approach (Nüsslein-Volhard, C. \& Dahm, R., eds), pp. 59-92. Oxford: Oxford University Press.

Stainier, D. Y. R. (2001). Zebrafish genetics and vertebrate heart formation. Nature Reviews/Genetics 2, 39-48.

Thisse, C. \& Zon, L. I. (2002). Organogenesis - Heart and blood formation from the zebrafish point of view. Science 295, 457-462.

Tracy, H. C. (1926). The development of motility and behavior reactions in the toadfish (Opsanus tau). Journal of Comparative Neurology 40, 253-369.

Tracy, H. C. (1959). Stages in the development of the anatomy of motility of the toadfish (Opsanus tau). Journal of Comparative Neurology 111, 27-82.

Weinstein, B. M., Schier, A. F., Abdelilah, S., Malicki, J., Solnica-Krezel, L., Stemple, D. L., Stainier, D. Y., Zwartkruis, F., Driever, W. \& Fishman, M. C. (1996). Hematopoietic mutations in the zebrafish. Development 123, 303-309.

Westerfield, M. (1989). The Zebrafish Book: a Guide for the Laboratory Use of Zebrafish (Brachydanio rerio). Eugene, OR: University of Oregon Press.

Zon, L. (1995). Developmental biology of haematopoiesis. Blood 86, 2876-2891. 